\title{
Exchange Relationships and the Environment: The Acceptability of Compensation in the Siting of Waste Disposal Facilities
}

\author{
EDMUNDO CLARO*
}

Alfredo Lecannelier 1945, Of. 2

Providencia

Santiago, Chile

Email:edmundo.claro@rides.cl

\begin{abstract}
Within siting literature there is strong agreement that compensation for environmental risks is a necessary condition for local acceptance of waste treatment facilities. In-kind compensation is commonly pushed forward as being more effective than financial benefits in reducing local opposition. By focusing on the siting of a sanitary landfill in Santiago, Chile, this paper explores the performance of both types of compensation and relates the analysis to the notion of social norms of exchange. These are understood as being based on three main types of social relations: care, justice and freedom. Whereas monetary compensation is associated with market relations based on freedom and the offer of in-kind compensation to egalitarian relations based on justice, the absence of compensation is linked to fraternal relations based on care. It is argued that in-kind compensation is more acceptable than monetary payments or no compensation because people tend to understand siting conflicts more as matters of justice rather than as matters of freedom or care.
\end{abstract}

\section{KEYWORDS}

Waste, NIMBY, compensation, exchange relations

\footnotetext{
* Associate Researcher, RIDES, Chile and Associate Researcher, Facultad de Ciencias de la Salud, Universidad Diego Portales, Chile.
} 


\section{EDMUNDO CLARO}

\section{INTRODUCTION}

Domestic solid waste (DSW) management is an important activity for every city, as it provides the means for the achievement of a considerable part of urban hygienic requirements. It basically consists of four stages: collection, transport, treatment and disposal. Although all these are sources of significant social discomfort, the fourth causes continual and major conflicts between operators of waste disposal facilities, authorities and host communities. As some authors argue, 'In many cases, organized host community opposition to proposed waste disposal facilities can be expected to prevail independent of a given project's net social value' (Himmelberger, Ratick and White, 1991: 647). Consequently, the location of new DSW facilities is a complex and difficult endeavour in which technical, environmental, economic, social and political factors need to be co-ordinated.

It is commonplace in the broad siting literature to argue that in this kind of situation compensation plays an important role in resolving siting disputes (Himmelberger et al., 1991; Hunold and Young, 1998; O'Hare, Bacow and Sanderson, 1983; Rabe, 1994). More specifically, there appears to be some agreement that conventional economic theory assumes that individual monetary compensation offers increase the willingness to accept locally unwanted projects (Frey, Oberholzer-Gee and Eichenberger, 1996; Groothuis, Van Houtven and Whitehead, 1998; O'Hare et al., 1983). In practice, however, price incentives are unsuccessful. In view of this, many authors have argued that in-kind or public goods compensation is more effective in gaining local acceptance than financial incentives (Field, Raiffa and Susskind, 1996; Frey et al., 1996; Kunreuther and Easterling, 1992, 1996; Mansfield, Van Houtven and Huber, 1998; O'Hare et al., 1983).

By focusing on a Santiago siting case, this paper analyses how monetary compensation schemes tend to perform worse than public goods ones and the reasons behind this variance. Standard economic choice theory explains this difference entirely in terms of self-interested consequential reasoning by affected agents (Frey et al., 1996; Mansfield et al., 1998). From this perspective, agents tend to prefer public goods compensation because it maximises their own net benefits. In contrast to this approach, this paper develops a procedural account of this phenomenon in which specific social norms based on the relation of the involved parties determine which kinds of exchanges are appropriate and which are not (Fiske and Tetlock, 1997; Medin, Schwartz, Blok and Birnbaum, 1999; Zelizer, 1998). Accordingly, an agent rejects financial payments and agrees to public goods compensation not because this yields higher benefits to him/her but because this seems the correct or appropriate way of behaving.

Soma (2006: 41) points out that at the 'centre of environmental conflicts are arguments about justice and fairness in the distribution of environmental goods and harms'. Locating a new waste disposal facility clearly reflects this 


\section{EXCHANGE RELATIONSHIPS AND THE ENVIRONMENT}

phenomenon as it usually implies important positive and negative changes for affected individuals when compared to the possibility of not having the facility built. On the positive side, waste disposal facilities are normally beneficial for a widespread and numerous population, including those whose waste is treated and those who do the treatment. On the negative side, they usually concentrate considerable health risks, environmental threats and economic costs locally in the host community (Lidskog, 1998; Pommerehne et al., 1997; Rabe, 1994). As such, waste disposal facilities imply a tension between the regional and the local (Lidskog, 2001). While from a regional perspective the location of the facility is a necessity, from a local viewpoint it is an appalling burden or negative development (Lidskog, 1998).

In research dealing with distributive justice in general, or as applied to more specific issues, there are three basic distribution rules: equity, equality and need of the resource in question (Mannix, Neale and Northcraft, 1995; Renn, Webler and Kastenholz, 1998; Sabbagh, Dar and Resh, 1994; Sondak, Neale and Pinkley, 1995). Whereas equity requires that each person or unit be allocated an amount of resources or goods in proportion to what they contribute to their production or availability, equality requires that all should be allocated the same amount of what is being distributed. The principle of need basically states that each person should be allocated an amount of a resource grounded on his/her relative need for the resource in question.

Focusing on the geographic unfairness linked to the siting of waste disposal facilities, I disregard the equity rule, as distributing the associated burdens in accordance to each person's waste contribution or input seems difficult. As I am not aware of people in need of waste destined for final disposal, I also omit the distributive rule based on need. Concentrating on equality, where all contributors receive an equal distribution of burdens, there are three approaches to achieving this objective: a) elimination of all or most external costs from facilities; b) even redistribution of these burdens among those benefiting from these facilities; and c) fair compensation to those bearing the burdens by those benefiting from these facilities (Himmelberger et al., 1991).

Although there is ample space for mitigation or burden reduction measures (e.g., facility design, engineering upgrading and operation adjustments) (Himmelberger et al., 1991), a complete elimination of all external costs associated with waste disposal facilities is simply illusory, due to thermodynamic and economic reasons. ${ }^{1}$ At the same time, while downscaling and dispersing these facilities would surely redistribute the costs associated with living near a sanitary landfill, these actions will never completely eliminate geographical inequity. For each new and smaller waste disposal facility proposed, there would always exist tensions among those benefiting from it: those who live near to it will consider it unjust that they should bear all the costs and those that live far from it none.

The contents of this paper are as follows. The section following this introduction presents the fact that in-kind compensation is generally preferred to monetary 


\section{EDMUNDO CLARO}

payments, and gives the economic interpretation of this phenomenon. Section 3 reviews the anthropological literature regarding exchange, and interprets the preference for in-kind compensation over monetary compensation according to that framework. Section 4 presents the methodology used to empirically test the basic hypothesis of this research work, section 5 summarises the results of applying a survey to 600 people in Santiago and, finally, section 6 discusses some of the findings and gives indications for future research.

\section{IN-KIND VERSUS MONETARY COMPENSATION}

As complete elimination of burdens and/or their perfect distribution is not possible in practice, many attempts at obtaining an equal geographical distribution of burdens turn to compensation as a means to achieve it (Hunold and Young, 1998). As such, it is commonplace in the siting literature to argue that compensation plays an important role in resolving siting disputes (Himmelberger et al., 1991; Hunold and Young, 1998; O'Hare, Bacow and Sanderson, 1983; Rabe, 1994). Instead of eliminating burdens or redistributing them, compensation mechanisms recognise inequality in burden-bearing (Hunold and Young, 1998; Kunreuther and Easterling, 1996). In McMahon's (1991) terminology, compensation acknowledges that host communities are being treated unfairly by the beneficiaries of the facility as the latter are gaining inappropriately at the expense of the former. Therefore, compensation can be understood as a way of eliminating this unfairness by transferring resources from the beneficiaries of the project to those badly affected by it (Himmelberger et al., 1991; McMahon, 1991).

The idea of offering benefits to secure voluntary agreement from persons negatively affected by a proposed course of action is a very old one in economics (Groves, 1979). In the case of siting waste disposal facilities, the offer of compensation to reduce local opposition has been emphasised since the mid-1970s (O’Hare, Bacow and Sanderson, 1983). Diverse compensation mechanisms have been proposed and used in siting conflicts, including tax rebates, lower garbage collection fees, public goods and others. Conventional economic theory assumes that individual monetary compensation offers increase the willingness to accept locally unwanted projects (Frey et al., 1996; Groothuis et al., 1998; O'Hare et al., 1983). As O'Hare et al. (1983: 29) put it, according to economics, 'the concerns of facility opponents can always be assuaged by providing money to replace amenities that will be lost if the facility is built'.

In practice, price incentives do not seem to be successful (Field et al., 1996; Frey et al., 1996; Kunreuther and Easterling, 1990; O'Hare et al., 1983). As Frey et al. (1996: 1300) argue, 'To our knowledge, there is no single siting case in which compensation consisted of cash payments to individual residents living in the host community'. There is North American (Field et al., 1996; Kunreuther and 


\section{EXCHANGE RELATIONSHIPS AND THE ENVIRONMENT}

Easterling, 1990) as well as European (Frey et al., 1996) evidence that reflects the inconvenience of offering financial compensation. In these cases, it has failed to improve the rate of acceptance of such projects and has even substantially reduced acceptance. Frey et al. (1996) showed that while 50.8 per cent of the population of Wolfenschiessen, a small town in Switzerland, was willing to host a nuclear waste repository when no compensation was at stake, when financial compensation was offered, this fraction was reduced to 24.6 per cent.

In response to this, many argue that non-monetary or in-kind compensation presents considerable advantages in gaining public acceptance whenever a facility is being rejected by the local population (Frey et al., 1996; Kunreuther and Easterling, 1992, 1996; Mansfield et al., 1998; O'Hare et al., 1983). Supporting this argument, a study conducted in the USA showed that while a majority of people tend to refuse financial compensation when confronted with environmental losses, an important proportion of the population would be willing to accept as compensation the provision of other public goods (Mansfield et al., 1998). In addition, other studies conducted in the same country showed that citizens consider non-monetary benefits as both more effective in gaining public acceptance and more appropriate in siting procedures (Jenkins-Smith and Kunreuther, 2001; Kunreuther and Easterling, 1996).

When confronted by the fact that monetary compensation tends to perform worse than no compensation at all, the economic siting literature commonly describes it as the Bribe Effect. The exact source of this phenomenon is quite variable, extending from the moral repulsion people feel at comparing health with money (Gerrard, 1994) to the social shame associated with being seen as someone whose approval can be bought (Frey et al., 1996). Despite this variance, the Bribe Effect is usually ascribed to a negative feeling that appears within individuals as soon as they are offered money to accept hosting a waste disposal facility within their community. As such, it can be interpreted as a cost and therefore there is a preference for not experiencing it at all. Accordingly, people are seen as rejecting the offer of money when the sum of costs derived from the siting of the facility and the Bribe Effect is larger than the pecuniary benefits of agreeing to it, as accepting it when they are lower, and as remaining indifferent when they are equal.

There is another explanation in economic literature for the low performance of monetary compensation: the 'crowding-out' of civic duty or public spirit (Frey, 1997; Frey et al., 1996). The Crowding-out Effect explains that apart from monetary gains, there are also other kinds of ends people pursue, such as acting out of commitments, norms of behaviour or public spirit. It also argues that these ends are related, so that an increase in monetary gains might displace or destroy the possibility of individuals acting out of civic duty or public spirit. Thus, someone willing to accept the waste disposal facility for free in order to contribute to what he/she thinks to be a good solution to the collective problem of waste, might not be willing to accept it if offered money in return. This seems 


\section{EDMUNDO CLARO}

to happen because the offer of financial incentives diminishes individuals' sense of control over their choices, impairs their self-esteem and spoils their possibilities for self-expression (Frey, 1997; Lane, 1991).

Accordingly, in-kind or public goods compensation is favoured to monetary compensation because it yields higher expected net benefits in the utility or preference satisfaction calculus that agents perform when confronted with a siting proposal. More specifically, under this view in-kind compensation is more tolerated because a) it imposes lower moral costs than monetary rewards and therefore reduces the Bribe Effect (Frey, et al. 1996), and b) it is consistent with receiving utility from acting out of public spirit and thus reduces the Crowding-out Effect (Mansfield et al., 1998). Following modern consumer theory, these interpretations are based on a philosophy of preference utilitarianism and a restricted model of psychological behaviour (Spash, 2000). Following Spash (2000), they not only exclude non-utilitarian approaches to understanding this phenomenon but they also rule out any attempt to comprehend it in a non-consequentialist way.

In contrast to a purely consequentialist or instrumentalist notion of people, and in accordance with Aristotle, individuals here are seen as caring not only about the consequences of their actions but also about actions themselves. According to this approach people sometimes perform, or restrain from performing, a specific action because it is intrinsically appropriate, or inappropriate, not because it is a means toward a desired, or undesired, goal. As Nagel (1979) so neatly puts it, under these circumstances what matters is what one does, not what happens.

Accordingly, I do not understand the negative performance of monetary compensation solely as suggesting that the financial incentive is still too small to gain individuals' support for a problematic project. Instead, based on Smith's (1976) notion of propriety of actions, it can be interpreted as expressing that accepting monetary compensation for environmental losses lacks propriety as a way to resolve environmental conflicts (Jacobs, 1991). As such, the feelings of bribery associated with monetary incentives are a reflection that to treat the environment as just another commodity in the market place is the wrong way to value it (Anderson, 1993; Vatn, 2000). In other words, I would argue that these feelings do not spring from calculations performed by people but out of a norm of behaviour that indicates that the environment should not be traded for money.

\section{UNDERSTANDING EXCHANGE RELATIONSHIPS}

According to many anthropologists and most economists, exchange is one of the most important activities of society, if not actually the most important (Befu, 1977; Macneil, 1986). Independent of the real degree of importance of exchange 


\section{EXCHANGE RELATIONSHIPS AND THE ENVIRONMENT}

relations in society, there is a long tradition, mainly in anthropological literature, which concentrates on norms of behaviour establishing what is appropriate to be exchanged for what and under which circumstances. As Medin et al. (1999: 563) argue, 'there are consensual rules or principles that determine what kinds of exchanges are appropriate and how they will be interpreted'. In general terms, this literature argues that these cultural and moral norms place some limits on the set of possible exchanges so that some things 'cannot be traded for others no matter what the terms of the trade' (Carruthers and Espeland, 1998: 1394). The spirit behind these notions is differently known as 'blocked exchanges' (Andre, 1995), 'protected values' (Baron and Spranka, 1997) and 'taboo tradeoffs' (Fiske and Tetlock, 1997). According to Soma (2006), as the environment is commonly understood as composed of objects of moral concern, it is usually 'blocked' from being exchanged in the market.

Although these cultural rules usually do not define the precise kind and exact amount of goods and services to be exchanged, they generally prescribe a range of acceptable kinds and quantities of resources to be used in these interactions (Befu, 1977). Anthropologists usually interpret this phenomenon as discrete spaces of transactions in which different currencies are needed for different kinds of dealings (Douglas and Isherwood, 1979). These are usually called 'spheres of exchange' or 'economic spheres' (Bohannan, 1955; Douglas and Isherwood, 1979; Elster, 1979).

Despite the fact that rules of this kind are said to be present in all societies in some form or another (Vatn, 2000), this does not mean that they are the same in every society (Carruthers and Espeland, 1998). Nor does it mean that for every society these rules are constant in the sense of not changing through time. As societies vary in structure and cultural resources, so do their cultural systems of classifications, of which norms of exchange are only one product (Kopytoff, 1986). Thus, in contrast to pre-industrial small-scale societies, contemporary industrial ones appear to have a tendency to advance the use of market transactions at the expense of other modes of exchange or distribution in all domains of social interaction (Vatn, 2000). However, as Pálsson (1998: 277) argues, even in modern Western societies 'some items and services are taken to be beyond the laws and the realm of the marketplace'. In more legal terms, these goods are considered to be res extra commercium.

In line with the above, there is a common notion in economic anthropology in which exchange relations are classified according to three distinct criteria. Following Karl Polanyi, there are three modes of transaction: reciprocity, redistribution and market exchange (Dalton, 1971). Whereas reciprocity describes the circulation of goods in terms of generosity acts between kin and friends, and redistribution does it in terms of mandatory norms of justice controlled by a central authority, market exchange focuses on voluntary actions between anonymous self-interested parties (Dalton, 1971; van Staveren, 1999). These three kinds of exchange relations can be linked to van Staveren's (1999) three 


\section{EDMUNDO CLARO}

basic economic value domains: care, justice and freedom. She tells us that these principles belong to the core of the modern spirit as reflected by the French Revolution maxim fraternité, égalité, liberté. She argues that within each economic value domain resources should be allotted according to specific norms that govern the allocation of goods for that domain. Whereas under care relations goods circulate according to gift giving, and under justice relations in terms of a redistribution system, in freedom relations goods circulate according to market exchange. These value domains also specify the kind of institution that should rule or guide the allocation of goods. Thus, care relations usually allocate goods through domestic or civil institutions such as families and clubs, justice relations via the state, and freedom relations through the market (Godbout, 1998; van Staveren, 1999).

In line with this argument, this work follows Fiske (1992) and Fiske and Tetlock (1997) in their identification of three elementary and distinct forms of exchange relations: communal sharing, equality matching and market pricing. Under communal sharing relations goods are collectively owned and people disregard distinct individual identities, so that they 'often are willing to make enormous sacrifices for each other without expecting anything particular in return' (Fiske and Tetlock, 1997: 265). People act based on the interpersonal value of care and circulate goods mainly among close members of a group such as families and kin (Anderson, 1990; Fiske, 1990; van Staveren, 1999). People see goods as things they have in common and from which they "simply take what they need and contribute what they can, without anyone attending to how much each person contributes or receives' (Fiske, 1992: 693). In other words, it is an economic system governed by the giving of gifts (Anderson, 1990) that people pool as common resources (Fiske, 1990). ${ }^{2}$

In equality matching relations, people act moved by the public value of justice (van Staveren, 1999) and circulate goods among peers equally (Fiske, 1992). People understand goods as things to which everyone belonging to the same status has the same rights or receives the same share (Fiske, 1992). This can be interpreted as an economic system based on entitlements that people distribute equally among all. Under this system people keep track of how balanced the distribution of goods is (Boer, van Baalen and Kumar, 2002) and if found just they attempt to commit themselves to a course of action that is directed at the general interest or justice (Sunstein, 1991). Under equality matching relations, exchange patterns are based on quid pro quo motivations (Komter, 2001), so that each party's contributions are matched by similar things in return (Fiske, 1990). This means that compensations should take the form of equal or similar replacements (Fiske, 1992).

In market pricing relations, individuals are basically moved by the private value of freedom and circulate goods among anonymous persons (Anderson, 1990; Fiske, 1990; van Staveren, 1999). Goods under these relations are interpreted as something to be exchanged 'in return for something else of unlike 


\section{EXCHANGE RELATIONSHIPS AND THE ENVIRONMENT}

kind' after a voluntary and negotiated process (Fiske, 1990: 184). For that to happen, people usually have to reduce all relevant features under consideration to a single metric that enables complete comparisons (Boer et al., 2002). The basic motivation behind market pricing relations is: 'do I benefit from the transaction, do the costs involved outweigh the profits?' (Komter, 2001: 67). In other words, it is a social relation that evokes economic rationality. As such, it can be seen as an economic system based on the transactions of market commodities. Under market pricing relationships, everyone receives in proportion to what is exchanged, usually in the form of some common metric, like money (Fiske, 1992).

Coming back to the negative performance of monetary compensation in the siting of waste facilities, under this approach this can be interpreted in the following way: for some the tightness of exchange relations and its norms of behaviour are matters of profound commitment, so they tend to be offended when asked to make a trade-off perceived as not permitted by the relation they have assumed (Fiske and Tetlock, 1997). A tension arises when a potential host understands the siting situation in terms of a specific exchange relation and is offered in return for hosting the facility something that he/she considers inappropriate according to that relation. Thus, if someone framing the siting problem as a communal sharing relation, in the sense of being willing to host the waste disposal facility in his/her community for free, is offered some kind of compensation, then he/she might react with anger and indignation (Fiske and Tetlock, 1997). For this agent, accepting the offer of compensation for something he/she considers should be provided out of public spirit or civic duty might be considered as bribery (Frey et al., 1996). Thus, whereas the possibility of accepting money in return for hosting the waste facility only makes sense for people understanding siting decisions as belonging to the sphere of market exchange relations, the possibility of accepting public goods, or other in-kind compensation, only makes sense when siting decisions are seen as belonging to the sphere of equality matching relations.

\section{CASE STUDY DESIGN}

In order empirically to contrast the above propositions, and to analyse the acceptability of different compensation mechanisms, a survey instrument was designed and applied to 600 people in Santiago during August 2001. It was pre-tested in December 2000 and May 2001 where 70 interviews were administered. The pre-test showed that in general interviewees found the questions and tasks unproblematic.

In line with the contingent valuation method (CVM), this survey confronts respondents with the description of a change in an environmental good and a question in which they face a trade-off between that change and some other 


\section{EDMUNDO CLARO}

good. Focusing on the choice question, cases of locally unwanted land uses (LULUs), such as the siting of a sanitary landfill, are usually associated with property rights based on the existing municipality (Freeman, 1993). This implies that the trade-off question should be framed in terms of an exchange between a decrease in environmental quality and a gain in some other good, not the other way round (Freeman, 1993). Thus, instead of asking how much the respondent is willing to sacrifice in order to prevent the building of the sanitary landfill, the survey question needs to be framed in terms of how much, or what, is the agent willing to accept in order to support it.

This work follows those on the economic side of siting literature and uses the referendum format (Frey and Oberholzer-Gee, 1996; Kunreuther and Easterling, 1990; Groothuis et al., 1998). Following Freeman (1993), CVM surveys consist of two basic components: a) a description of the environmental change which the respondent is to imagine, and b) the choice question. Concentrating on the first, what follows is how respondents were confronted with the change in environmental quality:

The new sanitary landfill will last approximately 15 years and will treat approximately 4,000 tons of garbage daily. This means that around 600 trucks per day will be disposing their wastes in the landfill during this period of time. According to experts in the field, including academics, engineers and sanitary and environmental authorities, it is expected that apart from truck traffic, no other environmental impact will occur, except some bad smell problems during rainy periods.

In order to analyse the interaction between exchange relations and the willingness of respondents to host the sanitary landfill within their municipality, three different choice questions were created based on different compensation mechanisms: no compensation, public goods compensation and monetary compensation. These different compensation mechanisms are assumed to represent different exchange relations in the following way:

\begin{tabular}{|lll|}
\hline Compensation mechanism & & Exchange relation \\
\hline No compensation & $\rightarrow$ & Communal sharing \\
Public goods compensation & $\rightarrow$ & Equality Matching \\
Monetary compensation & $\rightarrow$ & Market pricing \\
\hline
\end{tabular}

FIGURE 1. Compensation mechanisms and exchange relations

In contrast to empirical work where each respondent is confronted with different compensation mechanisms and asked to respond to them (Frey et al., 1996; Jenkins-Smith and Kunreuther, 2001), here the approach is based on in- 


\section{EXCHANGE RELATIONSHIPS AND THE ENVIRONMENT}

dependent samples experiments or between subjects experiments (Kinnear and Gray, 2000). Accordingly, the survey was divided into three different groups: one control and two experimental. Whereas the control group was asked to express whether they would vote in favour of the project becoming reality with no compensation in return, the two experimental groups were asked the same referendum question but including some extra benefits. While one experimental group was offered monetary payments in exchange, the other included the provision of public goods.

\section{EMPIRICAL RESULTS}

\subsection{Assessing the acceptability of different compensation mechanisms}

Based on all responses given by respondents, a sanitary landfill was accepted by 11 percent of the sample, rejected by 84 percent, 5 percent were undecided and 1 percent did not give an answer (see Table 1).

TABLE 1. Frequency of responses to the referendum question

\begin{tabular}{cccccc}
\hline & Yes & No & $\begin{array}{c}\text { Don't } \\
\text { know }\end{array}$ & Refused & Total \\
\hline Frequency & 64 & 502 & 31 & 3 & 600 \\
\hline Per cent & 10.7 & 83.7 & 5.2 & 0.4 & 100 \\
\hline
\end{tabular}

As the outcome measure of interest here is willingness to vote for hosting the facility, we can simplify the four variable outcome responses into a binary outcome measure. This is achieved by grouping all non-positive responses together, and thus differentiating them from those responding affirmatively. Based on this measure, those not supporting the facility amounted to 89.3 percent.

The impact of different compensation mechanisms on the willingness of respondents to host the sanitary landfill within their municipality is shown in Table 2. In line with siting literature, it indicates that whereas monetary compensation performed worse than no compensation, public goods compensation performed better. A chi-square test of independence was used to see if their differences were statistically significant. With a statistic $\chi^{2}$ equal to 7.4 and two degrees of freedom, the probability of the null hypothesis, that the dependent variable is independent of compensation mechanism, is lower than 0.05. As such it should be rejected, thus confirming a significant association between compensation mechanism and response if no other variables are taken into consideration. This seems to indicate that in acceptability terms, 'monetary compensation' < 'no compensation' < 'public goods compensation'. 
EDMUNDO CLARO

TABLE 2. Frequency of responses by compensation mechanism

\begin{tabular}{lccc}
\hline \multirow{2}{*}{$\begin{array}{l}\text { Compensation } \\
\text { mechanism }\end{array}$} & Yes & $\begin{array}{c}\text { No, undecided or } \\
\text { refused }\end{array}$ & Total \\
\cline { 2 - 4 } No compensation & 21 & 179 & 200 \\
& $(10.5 \%)$ & $(89.5 \%)$ & $(100 \%)$ \\
Monetary compensation & 13 & 186 & 199 \\
& $(6.5 \%)$ & $(93.5 \%)$ & $(100 \%)$ \\
Public goods compensation & 30 & 171 & 201 \\
& $(14.9 \%)$ & $(85.1 \%)$ & $(100 \%)$ \\
\hline Total & 64 & 536 & 600 \\
& $(10.7 \%)$ & $(89.3 \%)$ & $(100 \%)$ \\
\hline
\end{tabular}

Chi-Square test: $\chi^{2}=7.40 ; \mathrm{df}=2 ; \mathrm{p}<0.05$.

\subsection{Examining the reasons why people tend to prefer public goods compensation to monetary payments}

All those respondents answering NO to the referendum question were asked some follow-up questions regarding the reasons for their answer. During the pre-test, immediately after respondents negatively answered the referendum question, they were asked to express the reasons for their previous answer in an open format. Although it has been argued that people are not always aware of the precise reasons that determine their choices (Shafir, Simonson and Tversky, 2000), it seems reasonable to suppose that their answers give at least some indication of the motives behind their voting behaviour.

Although many opposing responses were related to the negative impacts of the sanitary landfill, such as 'nuisance' (noise, bad smells, presence of flies and truck traffic), 'pollution' (pollution in general, smog and water pollution) and 'health' (presence of rats, increase in infections and illnesses), a great number of respondents provided reasons not purely based on the direct consequences of the facility. One of the most frequent responses was the inappropriateness of the 'place' selected for locating the sanitary landfill. Answers included that too many people would live close to it, that the neighbourhood was full of children, that there were more suitable places, etc. Another reason for opposing the location of the sanitary landfill was a lack of 'confidence' in terms of the landfill being safely managed. Lack of 'justice' responses included that the area is too polluted already and that rich communities are never targeted for these purposes. Other answers included the idea that 'property' prices would come down.

Focusing on negative responses associated to the 'compensation' offered, it is interesting to note that there are clear differences between the reasons given by people facing monetary compensation and those confronting public goods compensation. While a good fraction of the former argued that money 


\section{EXCHANGE RELATIONSHIPS AND THE ENVIRONMENT}

had 'nothing to do' with the situation they were confronting, or that it was an 'absurd offer', many of the latter said that they did not trust proponents that the compensation offered was going to take place. Table 3 provides with some representative examples of these responses.

TABLE 3. Compensation based reasons for voting NO in the pre-test referendum question

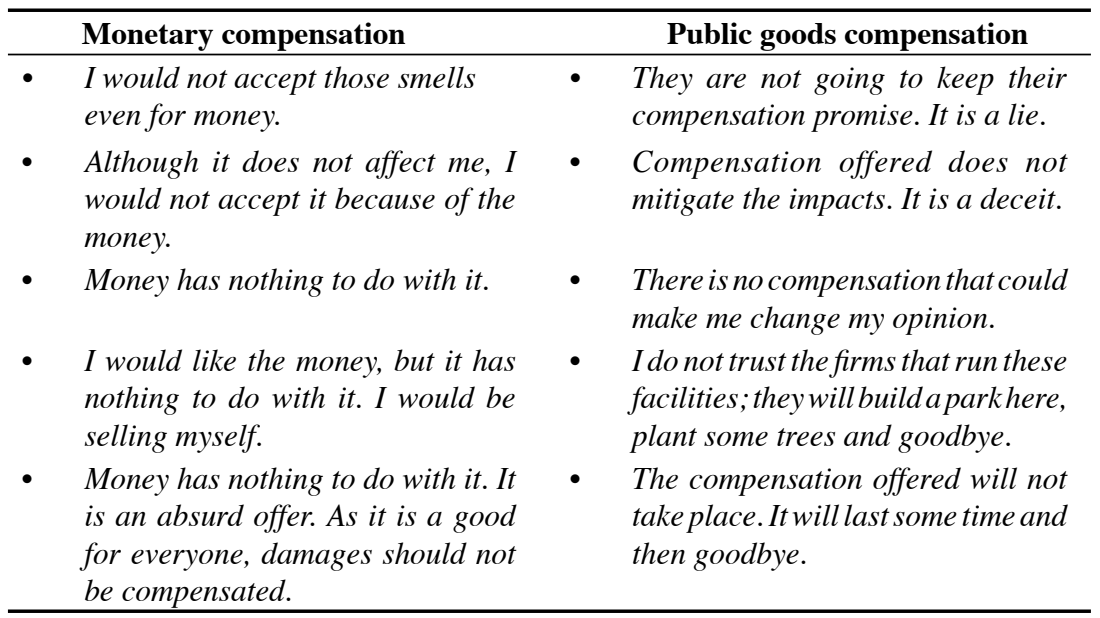

In order to better understand why respondents tend to prefer public goods compensation to monetary payments, the survey included some closed-ended questions asked immediately after respondents answered NO to either monetary or public goods compensation. Using a scale from 1 'It didn't influence me at all' to 5 'It influenced very much', they were asked to express how much had two reasons influenced in their response: a) the feeling of being bribed by the compensation offered, and b) finding the proposed compensation offer insufficient. Table 4 shows that these statements were rated significantly different under monetary compensation and public goods compensation.

TABLE 4. t-test to Reasons for voting NO

\begin{tabular}{lccccccc}
\hline \multirow{2}{*}{ Reason } & \multicolumn{3}{c}{ Mean } & \multicolumn{4}{c}{ t-test for Equality of Means } \\
\cline { 2 - 3 } \cline { 5 - 7 } & $\begin{array}{c}\text { Public goods } \\
\text { compensation }\end{array}$ & $\begin{array}{c}\text { Monetary } \\
\text { compensation }\end{array}$ & & t & df & $\begin{array}{c}\text { Sig. } \\
(2- \\
\text { tailed })\end{array}$ & Mean \\
\hline $\begin{array}{l}\text { Compensation } \\
\text { is a bribe }\end{array}$ & 3.4 & 3.9 & & -2.63 & 335 & 0.009 & -0.5 \\
$\begin{array}{l}\text { Compensation } \\
\text { is not enough }\end{array}$ & 3.2 & 2.2 & & 5.39 & 335 & 0.000 & 1.0 \\
\hline
\end{tabular}




\section{EDMUNDO CLARO}

In terms of respondents regarding the offer they confronted a bribe, monetary compensation was considered as such significantly more than public goods. This shows that respondents were more offended by the offer of monetary compensation than by the offer of public goods compensation. In relation to finding the offer insufficient, public goods compensation was regarded as such significantly more than cash payments. This suggests that enlarging the level of public goods compensation was seen as being able to increase acceptability rates more than increasing the level of monetary payments.

\subsection{Assessing the appropriateness of different compensation mechanisms}

Messick (1999: 13) argues that 'people make decisions in social situations by categorising the decision situation in terms of appropriateness'. In line with this, when told to assume that the sanitary landfill would not be located in their municipality, all respondents were asked to give 'appropriateness' weights to three different compensation procedures associated to the three norms of exchange elaborated in section three: communal sharing, equality matching and market pricing. More specifically, they were asked to rate in terms of appropriateness, from 1 'very inappropriate' to 4 'very appropriate', the three compensation situations shown in Figure 2.

\begin{tabular}{|c|c|c|c|c|}
\hline $\begin{array}{l}\text { Compensation } \\
\text { mechanism }\end{array}$ & & Exchange relation & & Compensation situation \\
\hline No compensation & $\rightarrow$ & Communal sharing & $\rightarrow$ & $\begin{array}{l}\text { Households affected by the } \\
\text { sanitary landfill should not } \\
\text { be compensated. }\end{array}$ \\
\hline $\begin{array}{l}\text { Public goods } \\
\text { compensation }\end{array}$ & $\rightarrow$ & Equality Matching & $\rightarrow$ & $\begin{array}{l}\text { Households affected by the } \\
\text { sanitary landfill should be } \\
\text { compensated with public } \\
\text { goods, such as schools, } \\
\text { hospitals, parks, etc. }\end{array}$ \\
\hline $\begin{array}{l}\text { Monetary } \\
\text { compensation }\end{array}$ & $\rightarrow$ & Market pricing & $\rightarrow$ & $\begin{array}{l}\text { Households affected by the } \\
\text { sanitary landfill should be } \\
\text { compensated with money. }\end{array}$ \\
\hline
\end{tabular}

FIGURE 2. Compensation situations used in the survey

Table 5 describes the results and it can be appreciated that the mean values of No compensation, Public goods compensation and Monetary compensation are equal to 1.89, 2.09 and 3.06 respectively. This provides a clear indication among these compensation situations in terms of appropriateness: no compensation < monetary compensation < public goods compensation. Table 6 confirms that all these differences are significant and therefore that this order is also significant. 
EXCHANGE RELATIONSHIPS AND THE ENVIRONMENT

TABLE 5. Frequency of compensation situations

\begin{tabular}{|c|c|c|c|c|c|c|c|}
\hline \multirow[b]{2}{*}{$\begin{array}{l}\text { Compensation } \\
\text { situation }\end{array}$} & \multirow[b]{2}{*}{$\mathbf{N}$} & \multicolumn{4}{|c|}{ Grade of appropriateness } & \multirow[b]{2}{*}{ Mean } & \multirow[b]{2}{*}{$\begin{array}{c}\text { Std } \\
\text { Devia- } \\
\text { tion }\end{array}$} \\
\hline & & 1 & 2 & 3 & 4 & & \\
\hline $\begin{array}{c}\text { No } \\
\text { compensation }\end{array}$ & $\begin{array}{c}597 \\
(100 \%)\end{array}$ & $\begin{array}{c}304 \\
(50.9 \%)\end{array}$ & $\begin{array}{c}145 \\
(24.3 \%)\end{array}$ & $\begin{array}{c}60 \\
(10.1 \%)\end{array}$ & $\begin{array}{c}88 \\
(14.7 \%)\end{array}$ & 1.89 & 1.09 \\
\hline $\begin{array}{l}\text { Public goods } \\
\text { compensation }\end{array}$ & $\begin{array}{c}600 \\
(100 \%)\end{array}$ & $\begin{array}{c}86 \\
(14.3 \%)\end{array}$ & $\begin{array}{c}71 \\
(11.8 \%)\end{array}$ & $\begin{array}{c}163 \\
(27.2 \%)\end{array}$ & $\begin{array}{c}280 \\
(46.7 \%)\end{array}$ & 3.06 & 1.08 \\
\hline $\begin{array}{c}\text { Monetary } \\
\text { compensation }\end{array}$ & $\begin{array}{c}599 \\
(100 \%)\end{array}$ & $\begin{array}{c}234 \\
(39.1 \%)\end{array}$ & $\begin{array}{c}158 \\
(26.4 \%)\end{array}$ & $\begin{array}{c}124 \\
(20.7 \%)\end{array}$ & $\begin{array}{c}83 \\
(13.9 \%)\end{array}$ & 2.09 & 1.07 \\
\hline
\end{tabular}

TABLE 6. t-test to Compensation situations

\begin{tabular}{|c|c|c|c|c|c|c|c|c|}
\hline \multirow[t]{2}{*}{ Pair* } & \multirow[t]{2}{*}{$\begin{array}{l}\text { Paired } \\
\text { Differences } \\
\text { Mean }\end{array}$} & \multirow[t]{2}{*}{$\begin{array}{c}\text { Std. } \\
\text { Deviation }\end{array}$} & \multirow[t]{2}{*}{$\begin{array}{l}\text { Std. } \\
\text { Error } \\
\text { Mean }\end{array}$} & \multicolumn{2}{|c|}{$\begin{array}{l}95 \% \text { Confidence } \\
\text { Interval of the } \\
\text { Difference }\end{array}$} & \multirow[t]{2}{*}{$\mathrm{t}$} & \multirow[t]{2}{*}{ df } & \multirow[t]{2}{*}{$\begin{array}{l}\text { Sig. } \\
(2- \\
\text { tailed })\end{array}$} \\
\hline & & & & Lower & Upper & & & \\
\hline NC-PGC & -1.181 & 1.692 & 0.069 & -1.317 & -1.045 & -17.052 & 596 & 0.000 \\
\hline PGC-MC & 0.972 & 1.405 & 0.057 & 0.859 & 1.084 & 16.925 & 598 & 0.000 \\
\hline $\mathrm{NC}-\mathrm{MC}$ & -0.211 & 1.651 & 0.068 & -0.344 & -0.079 & -3.127 & 595 & 0.002 \\
\hline
\end{tabular}

$* \mathrm{NC}=$ No compensation; $\mathrm{PGC}=$ Public goods compensation; $\mathrm{MC}=$ Monetary Compensation.

Thus, people tend to rate public goods compensation much higher than monetary compensation and monetary compensation higher than no compensation.

\section{DISCUSSION AND CONCLUSIONS}

This work provides information about the acceptability of different compensation mechanisms in the siting of a sanitary landfill in Santiago, Chile. The results of the survey tend to support the prevailing idea in the international siting literature that public goods compensation schemes perform better than monetary ones and that the latter do not perform better than no compensation at all. Results also show that people tend to feel more offended if they are offered monetary compensation than public goods compensation in exchange for accepting a sanitary landfill in their municipality. At the same time, there is evidence suggesting that increasing compensation levels in terms of public goods has a better chance 


\section{EDMUNDO CLARO}

of augmenting acceptability than increasing monetary payments. These results statistically confirm that monetary compensation appears to make less sense to people than public goods compensation.

The above views are confirmed by the reasons respondents gave for voting no or protesting in the referendum question during the pre-test of the survey. While a good fraction of respondents facing monetary compensation argued that money had nothing to do with the situation they were confronting, many participants facing public goods compensation said that they did not trust that the proponents would actually make the compensation that was offered. While this information is only part of the reasoning behind these individuals' voting behaviour, it does tell us a great deal about the suitability of both compensation measures. While cash compensation appears to many people to be absurd or something unworthy of consideration, in-kind or public goods compensation was acceptable but regarded as unlikely and therefore rejected.

The results of the survey also show that in terms of appropriateness, public goods compensation performs significantly better than both monetary compensation and no compensation. This appears to be indicating that citizens frame or understand the circulation of environmental goods in terms of equality matching relations, and not in terms of market pricing or communal sharing relations. This also reinforces the view that offering financial compensation for accepting environmental losses seems to be absurd in the Chilean case. Following Heyd (2004), this might be partly explained by a tendency in Latin America to resist, among other things, giving a purely market value to the environment. This phenomenon is also reinforced by the fact that in contrast to 'Northern' cultures Latin Americans appear to have an orientation to ethics which is less individualistic and more collectively oriented (Heyd, 2004). Thus, following Sunstein (1993) in his analysis of environmental policy and law, it can be argued that the results of the survey reflect that much public discussion about environmental goods has more to do with the appropriate mode than the appropriate level of valuation.

People's reaction to compensation mechanisms is then best understood in terms of the social relations (communal sharing, equality matching and market pricing) assumed by the parties to the transaction. This perspective permits not only the interpretation of failed compensation efforts, like protest responses in contingent valuation exercises, but also of successful compensation mechanisms. Most citizens consider environmental goods and services, like good air quality, ecological waste management and beautiful sights, as public goods to which every citizen has the same rights of access and obligations, rather than as private goods to be allocated to those with the greatest willingness to pay for them. ${ }^{3}$ Thus, when a typical citizen is asked about the monetary cost of his/her approval of a project with negative environmental impacts, he/she will be confused about the answer to be given. For some, these exchange barriers are so tight that they feel insulted at the question and may reject the whole enterprise. 


\section{EXCHANGE RELATIONSHIPS AND THE ENVIRONMENT}

Concerning successful compensation mechanisms, this understanding supports the common claim among some authors contributing to the siting literature that public goods compensation performs better than financial compensation in conflicts regarding the location of a waste disposal facility. As citizens mostly regard the environment as belonging to the sphere of equality matching, compensation for environmental losses should consist of similar replacements for what has been lost. As public goods are closer to environmental goods than money, mostly in that they are collective, it is no surprise that compensation based on them has a better acceptance than financial payments.

This perspective also explains the emphasis put by some industrialists, economists and policy-makers on the use of financial incentives to solve environmental problems. As most of them conceive of environmental goods as private commodities for which there can be clear and non-discriminatory property rights, the market is the obvious space for the regulation of its supply and demand. Thus, for example, using tradable permits for reducing industrial emissions might seem as the appropriate way of dealing with them, but it might not perform as well for the reduction of emissions coming from households. As some authors have shown, although in practice environmental economic instruments or incentives are rarely applied directly to consumers, they are much more commonly applied to firms (Frey, 1997).

This research indicates the need for institutions involved in the siting of waste disposal facilities to take different forms of compensation more seriously. There is a need to identify the appropriate social relations affecting any facility siting conflict and then to react with the corresponding offer of compensation, among other measures aimed at increasing the local acceptance of the waste disposal facility. From a broader perspective, it seems that the design and introduction of incentive mechanisms in the workings of society should be in line with the understanding held by the affected people of the goods and relations being touched by the mechanisms in question.

Siting a facility like a waste disposal plant involves many actors, including authorities, residents and the private sector. In order to understand siting processes, it seems necessary to do research on all actors. As this investigation covered mostly residents, doing compensation research focused on the rest of the actors would be fruitful both theoretically and practically. Industrialists were important actors in the Santiago case and said to be financing protest campaigns against sanitary landfills. As they see the sanitary landfill as negatively affecting the interests of their businesses, extending this kind of research to them would permit testing of whether they find monetary compensation more acceptable than residents do. It would also permit comparison of how acceptable industrialists find the other two compensation mechanisms: no compensation and public goods compensation.

It would be interesting to see how people react to different compensation mechanisms in the case of siting less environmentally negative facilities. For 


\section{EDMUNDO CLARO}

instance, how would local residents react to monetary compensation and public goods compensation when a shopping mall is at stake? Would these compensation mechanisms raise the same kind of concerns among local residents as with sanitary landfills?

It also seems worthwhile to focus future research on equality matching relations and its corresponding in-kind compensation. In first place, in-kind compensation is not restricted to the offer of local public goods, such as green areas, medical services and education facilities. The performance of compensation mechanisms based on other public goods can be explored, like the elimination of clandestine waste disposal sites and the restoration of damaged streets. Secondly, in-kind compensation need not be based on public goods exclusively. For example, it can take the form of limited and competitive education scholarships for the children of the affected households, it can be based on the offer of restricted job opportunities for the affected adults and so on. Thus, one objective for future research concerning compensation for environmental damage seems to point not only to the comparison of financial compensation and in-kind compensation, but also between different types of in-kind payments.

Finally, it is obvious that concentrating on compensation issues in the process of siting sanitary landfills does not address many important questions related to waste management. First, by focusing on sanitary landfills the issue of how industrial production and consuming patterns might be changed to minimise or eliminate much of the waste treated in these facilities remains open. Second, the emphasis on compensation mechanisms does not tackle some important procedural justice aspects of these siting processes, such as 'who has and ought to have the right to make decisions, and according to what procedures' (Hunold and Young, 1998: 85). Nevertheless, as in developing countries building and operating sanitary landfills is a widely used management option for handling wastes coming from households, commerce and the services industry, often generating serious conflicts, concentrating on this specific topic seems to be relevant. This is especially so if we want to develop compensation mechanisms which support voluntary solutions to this kind of conflict.

\section{NOTES}

I wish to express special thanks to Prof. Clive Spash for his continuing support through out the research process and for valuable comments on structure, substance and form. Ian Hodge was also very helpful during this process. In addition I would like to thank Michael Peters and an anonymous referee for valuable comments and suggestions.

In May 2005, a similar version of this paper was presented at the conference 'Waste - the Social Context' in Edmonton, Canada, organized by the Edmonton Waste Management Centre of Excellence and the Department of Civil and Environmental Engineering, University of Alberta, Edmonton. 


\section{EXCHANGE RELATIONSHIPS AND THE ENVIRONMENT}

${ }^{1}$ In accordance with thermodynamics, whereas matter and energy cannot be created nor destroyed, they are continually flowing from one state to another and in that process making them less available for useful work. In other words, every physical process generates waste that will continue participating in the flow of matter and energy. The necessary flow of matter through our bodies is a constant confirmation of this principle. The food and drink we take from the environment and daily ingest is certainly transformed into vital things such as blood and bodily heat. However, we are well aware that alongside these beneficial products there is an important fraction of matter given back to the environment in the form of waste.

${ }^{2}$ In rigour, Fiske (1992) and Fiske and Tetlock (1997) identify four elementary forms of social relations. However, the form labelled 'authority ranking' is not considered here because it does not seem to be relevant for the case at hand. As Earle and Cvetkovich (1999: 16) argue when exploring the relevance of Fiske's forms of social relations for explaining social trust in environmental risk management contexts, 'too few of our respondents fell into this category [authority ranking] for inclusion in the study'.

${ }^{3}$ This interpretation is similar but not equal to that provided by Soma (2006: 37). According to her, environmental goods are better understood as 'shared goods ... in which people have a common interest and for which they share responsibility'.

\section{REFERENCES}

Anderson, E. 1990. 'The ethical limitations of the market'. Economics and Philosophy 6: $179-205$.

Anderson, E. 1993. Value in Ethics and Economics. Cambridge, Massachusetts: Harvard University Press.

Andre, J. 1995. 'Blocked exchanges: a taxonomy', in D. Miller and M. Walzer (eds), Pluralism, Justice, and Equality (Oxford: Oxford University Press), pp. 171-196.

Baron, J. and M. Spranka. 1997. 'Protected values', Organizational Behavior and Human Decision Processes 70(1): 1-16.

Befu, H. 1977. 'Social exchange', Annual Review of Anthropology 6: 255-281.

Boer, N-I., P.J. van Baalen and K. Kumar. 2002. 'The importance of society for understanding knowledge sharing processes in organizational contexts', ERIM Report Series Research in Management ERS-2002-05-LIS, February, Erasmus Universiteit Rotterdam.

Bohannan, P. 1955. 'Some principles of exchange and investment among the Tiv'. American Anthropologist 57(1): 60-70.

Carruthers, B.G. W.N. and Espeland. 1998. 'Money, meaning, and morality'. American Behavioral Scientist 41(10): 1384-1408.

Dalton, G. 1971. Economic Anthropology and Development: Essays on Tribal and Peasant Economics. New York: Basic Books.

Douglas, M. and B. Isherwood. 1979. The World of Goods: Towards an Anthropology of Consumption. New York: Routledge. 


\section{EDMUNDO CLARO}

Earle, T.C. and G. Cvetkovich. 1999. 'Social trust and culture in risk management', in G. Cvetkovich and R.E. Löfstedt (eds), Social Trust and the Management of Risk (London: Earthscan), pp. 9-21.

Elster, J. 1979. Ulysses and the Sirens: Studies in Rationality and Irrationality. Cambridge: Cambridge University Press.

Field, P., H. Raiffa and L. Susskind. 1996. 'Risk and justice: rethinking the concept of compensation'. Annals of the American Academy of Political and Social Science 545: $156-164$.

Fiske, A.P. 1990. 'Relativity within Moose ('Mossi') culture: four models for social relationships'. Ethos 18(2): 180-204.

Fiske, A.P. 1992. 'The four elementary forms of sociality: framework for a unified theory of social relations'. Psychological Review 99(4): 689-723.

Fiske, A.P. and P.E. Tetlock. 1997. 'Taboo trade-offs: reactions to transactions that transgress the spheres of justice'. Political Psychology 18(2): 255-297.

Freeman A.M. 1993. The Measurement of Environmental and Resource Values: Theory and Methods. Washington, D. C.: Resources for the Future.

Frey, B. 1997. Not Just for the Money: An Economic Theory of Personal Motivation. Cheltenham: Edward Elgar Publishing.

Frey, B. and F. Oberholzer-Gee. 1996. 'Fair siting procedures: an empirical analysis of their importance and characteristics'. Journal of Policy Analysis and Management 15(3): 353-376.

Frey, B., F. Oberholzer-Gee and R. Eichenberger. 1996. 'The Old Lady visits your backyard: a tale of morals and markets'. Journal of Political Economy 104(6): 1297-1313.

Gerrard, M.B. 1994. Whose Backyard, Whose Risk: Fear and Fairness in Toxic and Nuclear Waste Siting. Cambridge, Massachusets: The MIT Press.

Godbout, J.T. 1998. The World of the Gift. In collaboration with A. Caillé. Translated from the French by D. Winkler. Montreal/Kingston: McGill-Queen's University Press.

Groothuis, P.A., G. van Houtven and J.C. Whitehead. 1998. 'Using contingent valuation to measure the compensation required to gain community acceptance of a LULU: the case of a hazardous waste disposal facility'. Public Finance Review 26(3): 231-249.

Groves, T. 1979. 'Efficient collective choice when compensation is possible'. The Review of Economic Studies 46(2): 227-241.

Heyd, T. 2004. 'Themes in Latin American environmental ethics: community, resistance and autonomy'. Environmental Values 13(2): 223-242.

Himmelberger, J.J., S. Ratick and A.L. White. 1991. 'Compensation for risks: host community benefits in siting locally unwanted facilities'. Environmental Management 15(5): 647-658.

Hunold, C. and I.M. Young. 1998. 'Justice, democracy, and hazardous siting'. Political Studies 46(1): 82-95.

Jacobs, M. 1991. The Green Economy: Environment, Sustainable Development and the Politics of the Future. London: Pluto Press.

Jenkins-Smith, H. and H. Kunreuther. 2001. 'Mitigation and benefits measures as policy tools for siting potentially hazardous facilities: determinants of effectiveness and appropriateness'. Risk Analysis 21(2): 371-382. 


\section{EXCHANGE RELATIONSHIPS AND THE ENVIRONMENT}

Kinnear, P.R. and Gray, C.D. 2000. SPSS for Windows Made Simple: Release 10. Hove: Psychology Press.

Komter, A. 2001. 'Heirlooms, nikes and bribes: towards a sociology of things'. Sociology 35(1): 59-75.

Kopytoff, I. 1986. 'The cultural biography of things: commoditization as process', in A. Appadurai (ed.), The Social Life of Things: Commodities in Cultural Perspective (Cambridge: Cambridge University Press), pp. 64-91.

Kunreuther, H. and D. Easterling. 1990. 'Are risk-benefit tradeoffs possible in siting hazardous facilities?' The American Economic Review 80(2): 252-256.

Kunreuther, H. and D. Easterling. 1992. 'Gaining acceptance for noxious facilities with economic incentives', in D. W. Bromley and K. Segerson (eds), The Social Response to Environmental Risk: Policy Formulation in an Age of Uncertainty (Boston: Kluwer Academic Publishers), pp. 151-186.

Kunreuther, H. and D. Easterling. 1996. 'The role of compensation in siting hazardous facilities'. Journal of Policy Analysis and Management 15(4): 601-622.

Lane, R. E. 1991. The Market Experience. New York: Cambridge University Press.

Lidskog, R. 1998. 'Social aspects of the siting of facilities for hazardous waste management'. Waste Management and Research 16(5): 476-483.

Lidskog, R. 2001. 'Siting conflicts - democratic perspectives and political implications'. Paper presented at the conference 'New Perspectives on Siting Controversy', Glumslöv.

Macneil, I.R. 1986. 'Exchange revisited: individual utility and social solidarity'. Ethics 96(3): 567-593.

Mannix, E.A., M.A. Neale and G.B. Northcraft. 1995. 'Equity, equality, or need? The effects of organizational culture on the allocation of benefits and burdens'. Organizational Behavior and Human Decision Process 63(3): 276-286.

Mansfield, C., G. Van Houtven and J. Hube. 1998. 'Compensating for public harms: why public goods are preferred to money', Working Paper, Duke University.

Markham, A. 1994. A Brief History of Pollution. London: Earthscan.

McMahon, C. 1991. 'The paradox of deontology'. Philosophy and Public Affairs 20(4): 350-377.

Medin, D.L., H.C. Schwartz, S.V. Blok and L.A. Birnbaum. 1999. 'The semantic side of decision making'. Psychonomic Bulletin and Review 6(4): 562-569.

Messick, D.M. 1999. 'Alternative logics for decision making in social settings'. Journal of Economic Behavior and Organization 39(1): 11-28.

Nagel, T. 1979. 'The fragmentation of value', in his Mortal Questions (Cambridge: Cambridge University Press), pp. 128-141.

O'Hare, M., L. Bacow and D. Sanderson. 1983. Facility Siting and Public Opposition. New York: Van Nostrand Reinhold.

Pálsson, G. 1998. 'The virtual aquarium: commodity fiction and cod fishing'. Ecological Economics 24(2-3): 275-288.

Passmore, J. 1974. Man's Responsibility for Nature. London: Duckworth. 


\section{EDMUNDO CLARO}

Pommerehne, W.W., A. Hart and F. Schneider. 1997. 'Tragic choices and collective decision-making: an empirical study of voter preferences for alternative collective decision-making mechanisms'. The Economic Journal 107(442): 618-635.

Rabe, B.G. 1994. Beyond NIMBY: Hazardous Waste Siting in Canada and the United States. Washington, D.C.: The Brookings Institution.

Renn, O., T. Webler and H. Kastenholz. 1998. 'Procedural and substantive fairness in landfill siting: a Swiss case study', in R.E. Löfstedt and L. Frewer(eds), The Earthscan Reader in Risk and Modern Society (London: Earthscan), pp. 253-270.

Sabbagh, C., Y. Dar and N. Resh. 1994. 'The structure of social justice judgements: a facet approach'. Social Psychology Quarterly 57(3): 244-261.

Shafir, E., I. Simonson and A. Tversky. 2000. 'Reason-based choice', in D. Kahneman and A. Tversky (eds), Choices, Values, and Frames (Cambridge: Cambridge University Press), pp. 597-619.

Smith, A. 1976. The Theory of Moral Sentiments, ed. D.D. Raphael and A.L. Macfie. Indianapolis: Liberty Fund.

Soma, K. 2006. 'Natura economica in environmental valuations'. Environmental Values 15(1): 31-50.

Sondak, H., M.A. Neale and R. Pinkley. 1995. 'The negotiated allocation of benefits and burdens: the impact of outcome valence, contribution, and relationship'. Organizational Behavior and Human Decision Processes 64(3): 249-260.

Spash, C.L. 2000. 'Ethical motives and charitable contributions in contingent valuation: empirical evidence from social psychology and economics'. Environmental Values 9(4): 453-479.

van Staveren, I. 1999. Caring for Economics: An Aristotelian Perspective. Delft: Eburon.

Sunstein, C.R. 1991. 'Preferences and politics'. Philosophy and Public Affairs 20(1): 3-34.

Sunstein, C.R. 1993. 'Endogenous preferences, environmental law'. Journal of Legal Studies 22(2): 217-254.

Vatn, A. 2000. 'The environment as a commodity'. Environmental Values 9(4): 493-509.

Zelizer, V. 1998. 'How do we know whether a monetary transaction is a gift, an entitlement, or compensation?' in A. Ben-Ner and L. Putterman (eds), Economics, Values, and Organization (Cambridge: Cambridge University Press), pp. 329-333. 